\title{
COVID-19 and perioperative nursing - inside the NSW State Emergency Operation Centre
}

Follow this and additional works at: https://www.journal.acorn.org.au/jpn

Part of the Health Services Administration Commons, Health Services Research Commons, Perioperative, Operating Room and Surgical Nursing Commons, and the Surgery Commons

c) (i)

This work is licensed under a Creative Commons Attribution 4.0 License.

\section{Recommended Citation}

Waller, Sarah-Jane (2020) "COVID-19 and perioperative nursing - inside the NSW State Emergency Operation Centre," Journal of Perioperative Nursing: Vol. 33 : Iss. 3 , Article 1.

Available at: https://doi.org/10.26550/2209-1092.1091

https://www.journal.acorn.org.au/jpn/vol33/iss3/1

This Editorial is brought to you for free and open access by Journal of Perioperative Nursing. It has been accepted for inclusion in Journal of Perioperative Nursing by an authorized editor of Journal of Perioperative Nursing. 


\section{COVID-19 and perioperative nursing - inside the NSW State Emergency Operation Centre}

For Australia-wide advice and information on the COVID-19 pandemic please see www.australia.gov.au. Links to state and territory information and advice for health professionals are also accessible from this page.

When I was asked to write this editorial, I felt honoured. When I sat down to write it, however, I felt terrified, underqualified and not sure if I was up to the task. As I stopped to reflect, I also realised this is also how I felt when I first walked into the New South Wales (NSW) State Emergency Operation Centre (SHEOC) as a surgery liaison for the COVID-19 response in Sydney.

Like most people, I had only seen the inside of this centre in news broadcasts on bushfires, as this centre is home to the Rural Fire Service and the place from which bushfire response in NSW is led. Being there in person, it felt like I was at the NASA control centre - I was faced with a huge wall of TV screens with world maps, numerous TV channels and COVID-19 figures from across the world and domestically all on display. I saw the NSW Health Minister talking to Premier Berejiklian as I tried to orient myself and listen to what I was expected to do.

At this point, in early March, there had been no alteration to elective surgery in either the public or the private sector but the expectation of increased pressure on ward and ICU beds made it clear that a decision would need to be made. I worked with a colleague, clinical groups and elective surgery managers on what this could look like. We developed guidance for booking officers and ways of identifying patients affected by the pandemic so that in recovery we had a clear picture of what was needed. We spoke on teleconferences, took questions and sought clinical feedback about the way forward to balance the possible bed demands of COVID-19 and essential and urgent surgery. When the federal and NSW governments made the decision to put category 3 elective surgery such as total hip replacements and cataract surgery on hold, our focus moved to communication and consultation with both the public and private sector on case mix, availability of personal protective equipment (PPE) and workforce issues.

As perioperative nurses, we advocate for people when they are at their most alone and vulnerable and we're used to bringing the technical and the personal together ${ }^{1,2}$. We are also used to the dynamics of our work changing in a phone call and to facing challenging situations as a daily occurrence. When I was in the duty officer role at the SHEOC, I found myself seeking advice on everything from clinical waste for hotels being used to quarantine passengers returning from overseas through to reassuring a heavily pregnant woman that she would be allowed to have her partner in the birthing suite despite what she had read in the newspaper. Without a retractor in sight, I was part of the health team that has peeled back the layers of data, opinion and research to steer through issues from the many phone calls that are received.
Although the COVID-19 response is still underway, I have reflected on how I have applied my perioperative nursing skills in this unusual environment and would like to share these thoughts with you.

We are all in this together - even at 1.5 metres apart

The sterile field may now be 1.5 metres rather than 12 inches ${ }^{3}$ but this is still teamwork. Just as behind the double doors of the perioperative suite, each person in the SHEOC is interdependent on the rest of the team to ensure the best possible outcome for a patient and the community. Working as part of the COVID-19 response team, the support and trust the team has in each other, regardless of substantive positions, is phenomenal.

\section{Small acts of kindness aren't that small}

I arrived on Easter Monday ahead of a 10-hour duty officer shift to find a paper bag filled with chocolates with a handwritten thank you note. Small acts can have big effects. As a perioperative nurse we do this every day, from simple things like bringing a patient an extra blanket to a reassuring squeeze of the hand telling the patient that everything will be OK.

\section{The role of the patient has never been more central}

The way the community has embraced staying home except for 
essential activities, along with social distancing, washing hands and coughing into elbows, has meant that this has become the new norm in an incredibly short time. In reality, what the community is doing is making as much difference in addressing the pandemic as what we are doing. Empowering our patients in elective surgery through encouraging patient education and prehabilitation programs has a significant impact on patient outcomes 4 . If we can do this for COVID-19 why not for other wicked health problems we face?

I'd like to finish with a message of hope. It has been a privilege to work with such talented and dedicated health and emergency workers during this time. However, COVID-19 isn't the only wicked problem that health and society faces. I hope our efforts are also as unified and innovative in addressing the seven per cent of carbon emissions that are produced by the health sector each year and the up to 70 per cent of waste in health care facilities that is produced by operating theatres ${ }^{5,6}$.

Stay safe.

\section{References}

1. Schroeder M, Worrall-Carter L. Perioperative managers: Role stressors and strategies for coping. Contemp Nurse 2002;13(2-3):229-238 Available from: doi.org/10.5172/conu.13.23.229.

2. Glover D, Newkirk L, Cole L, Walker T, Kelly C, Nader C. Perioperative clinical nurse specialist role delineation: A systematic review. AORN J 2006;84(6):1017-1030. Available from: www.sciencedirect.com/ science/article/abs/pii/S0001209206639999.
3. MCCallister L. OR Basics: The sterile field [Internet]. MassDevice Medical Network; 2010 [cited 2020 May 5]. Available from: www.massdevice.com/or-basics-sterile-field.

4. Cabilan C, Hines S, Munday J. The effectiveness of prehabillitation or preoperative exercise for surgical patients: A systematic review. JBI Database System Rev Implement Rep 2015;13, (1):146-187. Available from: www.ncbi.nlm.nih.gov/ pubmed/26447015.

5. Bryan A, Doran G, Flakelar C, Howitt J, Oelgemoller, Shields L. Clinical waste - a major environmental burden [Internet]. Sydney: Hospital and Healthcare; 2019 [cited 2020 May 5]. Available from: www.hospitalhealth.com.au/content/ design-in-health/article/clinicalwaste-a-major-environmental-burden53426063\#axzz6KIPrHypH.

6. Malik A, Lenzen M, McAlister S, McGain F. The carbon footprint of Australian health care. Lancet Planet Health 2018;2(1):e27e35. Available from: www.thelancet. com/journals/lanplh/article/PIIS254251961730180-8/fulltext. 